\title{
Geological characteristics and geotechnical properties of Eocene and Quaternary deposits on the Belgian continental shelf: synthesis in the context of offshore wind farming
}

\author{
S. Le Bot ${ }^{1 *}$, V. Van Lancker ${ }^{1}$, S. Deleu ${ }^{1}$, M. De Batist ${ }^{1}$, J.P. Henriet ${ }^{1}$ \& W. Haegeman ${ }^{2}$ \\ 1 Renard Centre of Marine Geology, Geology and Soil Sciences, Ghent University, Krijgslaan 281, S8, 9000 - Ghent, Belgium \\ * Present adress: UMR CNRS 6143 Morphodynamique continentale et côtière, University of Rouen, 76821 - Mont Saint Aignan Cedex. \\ Email: sophie.lebot@univ-rouen.fr (corresponding author) \\ 2 Laboratorium Grondmechanica, Civiele Techniek, Ghent University, Technologiepark 905, 9052 - Zwijnaarde, Belgium
}

Manuscript received: January 2004; accepted: November 2004

\begin{abstract}
The present study consists of a synthesis of the lithostratigraphy, geotechnical properties, geometry and distribution of Eocene and Quaternary deposits of the Belgian continental shelf. It is based on available large datasets (seismics, cores, cone penetration tests) and their interpretations synthesised from numerous studies from the last 20 years. A significant effort has been focused on data digitisation and integration into appropriate GIS software packages in order to compare the data in a much more dynamic and flexible way. New insights have been proposed on the lithostratigraphy and geotechnical properties of offshore and onland deposits.

An application is presented for the selection of wind farm implantation sites. Geological and geotechnical aspects of direct interest for wind farm implantation site selection have been focused on, such as the stability of the offshore wind turbine structures and the minimization of environmental impacts on the seabed. Sites suitable for wind turbines using monopile structures on the Belgian continental shelf are proposed.
\end{abstract}

Keywords: Belgian continental shelf, Eocene, Quaternary, seismic stratigraphy, lithostratigraphy, deposit geometry, geotechnics, wind turbines

\section{Introduction}

Given the contribution expected from offshore wind energy in Belgium, a scientific assessment has been conducted of the feasibility of offshore wind farming on the Belgian continental shelf (Van Hulle et al., 2004). Aim was to develop a long-term strategy for the selection of offshore wind farm sites in the view of a sustainable development. Together with studies of the wind potential, structure design and electrical aspects, the assessment also involved a geological study, as recommendations for the selection of potential wind farm implantation sites require a sound knowledge of the most relevant geoparameters and their spatial distribution.

Since the early 80's, numerous studies have been conducted on various aspects of the geology of the Belgian continental shelf: e.g. Cenozoic seismic stratigraphy and structural setting
(De Batist, 1989; De Batist \& Henriet, 1995), Cenozoic lithostratigraphy and sequence stratigraphy (Jacobs et al., 1990; Jacobs \& Sevens, 1993; Jacobs \& De Batist, 1996) and Quaternary seismic stratigraphy and palaeomorphology (Mostaert et al., 1989; Liu et al., 1992, 1993).

In this paper, we will present a synthesis of the lithostratigraphy, geometry and distribution, and geotechnical properties of the deposits on the Belgian continental shelf, based on a digital compilation of all existing data sets, on an overview of the previous interpretations, but also on new data and new interpretations. We will propose new insights in the lithostratigraphy and geotechnical properties of offshore and onshore deposits from the correlation of offshore cores with seismic data, and from the interpretation of cone penetration tests to aid in the stratigraphic correlation of onshore and offshore strata. Finally, we will present a map of the most and 
least suitable sites for windfarm implantation in case of monopile structures, based on criteria such as stability and minimization of the environmental impacts on the seabed.

We will focus only on Quaternary deposits and on Eocene strata subcropping below the Quaternary cover, as only these are relevant for supporting wind mill piles $(<20 \mathrm{~m}$ into the seabed). Oligocene, Miocene and Pliocene deposits are lacking on most parts of the continental shelf due to intensive erosion in Neogene and Pleistocene times, and Paleocene deposits are too deeply buried.

\section{Data}

The main geological and geotechnical data and results that have been used for this study, consist of seismic profiles, sediment cores and cone penetration tests.

\section{Seismic data}

The offshore seismic data constitute the largest and most useful dataset. Since 1978, a dense and regular highresolution reflection seismic grid with a total length of about $16,000 \mathrm{~km}$ has been acquired on the Belgian continental shelf and on the adjacent French, Dutch and UK sectors by the Renard Centre of Marine Geology (Ghent University) in the framework of several projects (Maréchal \& Henriet, 1983; Maréchal et al., 1986; Henriet et al., 1988; De Batist et al., 1989; Mostaert et al., 1989; De Batist \& Henriet, 1995) (Fig. 1).

These seismic data have been interpreted in terms of seismic stratigraphy, geometry and distribution of the Cenozoic deposits (Henriet et al., 1988; De Batist et al., 1989, De Batist, 1989; De Batist \& Henriet, 1995). Integration of lithostratigraphic information from boreholes and sediment cores have

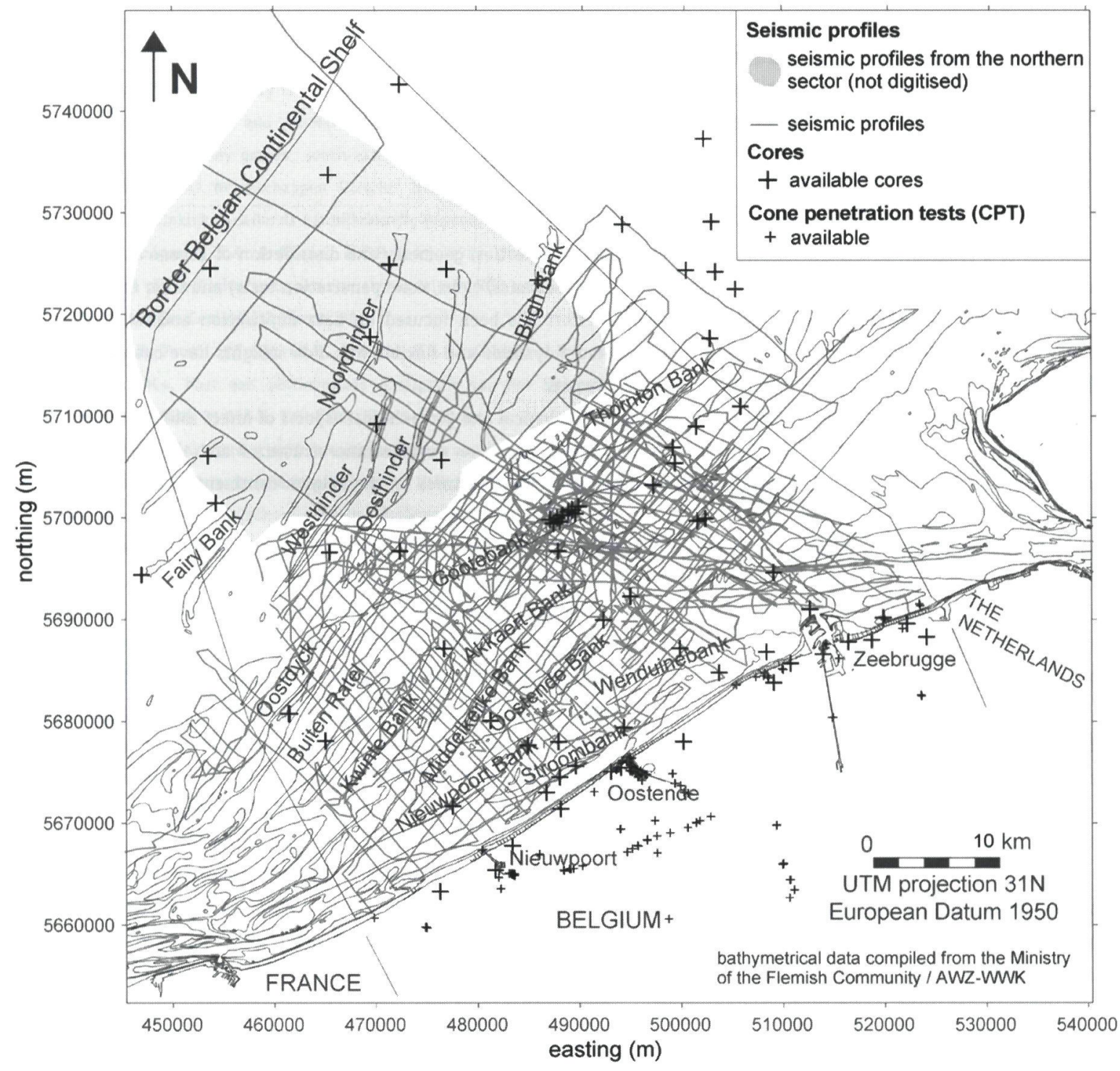

Fig. 1. Location of available seismic profiles, cores and cone penetration tests.

Seismic data have been provided by RCMG (Ghent University), boreholes and cores by the Belgian (BGD) and Dutch (TNO-NITG) Geological Surveys and cone penetration tests by the 'Databank Ondergrond Vlaanderen' (Ministry of the Flemish Community, Department of Geotechnics). 
allowed Jacobs \& De Batist (1996) to determine depositional environments and establish a sequence-stratigraphic framework.

For this paper, we have re-compiled the existing seismic data and synthesised the results of these previous studies in terms of stratigraphy, geometry and distribution of the Cenozoic deposits.

\section{Core information}

A second important data set consisted of 79 sediment cores (Fig. 1), of which 64 were taken offshore and 15 onshore (maximum $20 \mathrm{~km}$ from the coastline). These cores are generally not longer than $10 \mathrm{~m}$. Only 37 of them penetrate the base of the Quaternary cover and Eocene deposits. The sediment cores were mainly collected by the former Rijks Geologische Dienst (RGD, NL), the Belgische Geologische Dienst (BGD) and OSIRIS Survey (NL).

In the near-shore area, detailed lithostratigraphic information from 4 deeper boreholes was correlated with seismic information by Jacobs \& Sevens (1993) and Jacobs \& De Batist (1996). A large variety of analysis performed on some cores by RGD, BGD and OSIRIS Survey provide valuable indications on deposit ages (e.g. microfossil analysis), sedimentology and lithostratigraphy (e.g. grain-size and sedimentary facies analysis).

For this paper, we have re-interpreted the lithostratigraphy of the offshore deposits, based on a revised correlation of information from offshore cores and seismic data.

\section{Cone penetration tests}

The third major data set consisted of cone penetration tests. Most were conducted onshore, however few cone penetration tests are available offshore in areas where infrastructure works have been carried out: e.g. near the harbour of Zeebrugge (Depret, 1981) and at the 0ostdijck and Westhinder sand banks (Fig. 1). Most of the cone penetration tests were conducted by the Ministry of the Flemish Community (Department of Geotechnics) and made available through the 'Databank Ondergrond Vlaanderen' (DOV).

For this paper, we integrated for the first time cone penetration test data with seismic and lithological information on a regional scale. The cone resistance parameter from 165 selected cone penetration tests was used to obtain information on the geotechnical and lithological characteristics of geological units. The cone penetration tests were selected on basis of the following criteria: (1) tests with available stratigraphic interpretation, delivered by DOV, were first considered, (2) secondly, their location was taken into account: onshore CPT's not too far from the coast were preferred in the view of offshore correlation, and attention has been paid to select tests conducted in every geological unit, and (3) thirdly, only the tests penetrating deeper than $25 \mathrm{~m}$ were selected, to get information on pre-Quaternary deposits as well.

\section{Methodology}

\section{Data compilation and assessment}

The compilation and integration of these large amounts of data and results from previous studies has represented a considerable effort. Most of the data existed only in analogue format, and an important part of the work involved digitization of the data and their subsequent integration in appropriate GIS software packages to allow dynamic and flexible data comparison and to aid in the final mapping of suitable sites for wind farm implantation. The summary maps and diagrams presented in this paper were generated from this GIS compilation.

\section{Correlation methods}

The lithostratigraphy of offshore deposits was established by correlating seismic-stratigraphic data with offshore coring information, i.e. by comparing the depths of the lithostratigraphic boundaries (in cores) with the depths of the seismicstratigraphic and seismic facies boundaries at the same offshore location. However, cores and cone penetrating tests are quite scarce on the shelf, due to the complex logistics required to collect them, and they are mostly confined to near-shore locations. When offshore data were lacking or scarce, the assessment of the lithological and geotechnical characteristics of offshore deposits was done by extrapolating onshore information to corresponding offshore units. From the onshore cone resistance profiles, distinct units were identified on the basis of the values of the cone resistance parameter and the pattern (homogenous or heterogeneous). Then, a correlation was made between coring information and cone resistance parameter interpretation in terms of lithostratigraphy and geotechnical properties of the geological units. This correlation is also based on the comparison of the depths of the lithostratigraphic boundaries (cores) and the depths of cone resistance facies (cone penetration tests) at the same near-shore location. Near-shore properties were then extrapolated to offshore geological units, guided by seismic stratigraphy and seismic facies interpretation.

\section{Eocene deposits}

\section{Seismic stratigraphy}

The structural setting and seismic stratigraphy of the Eocene deposits on the Belgian continental shelf was studied by De Batist (1989) and De Batist \& Henriet (1995). They identified within the Belgian offshore Eocene succession 8 seismicstratigraphic units and a number of sub-units based on seismic geometry and facies characteristics. Units are labelled Y1 to Y5, of Ypresian age, L1 and L2, of Lutetian age, B1, of Bartonian 

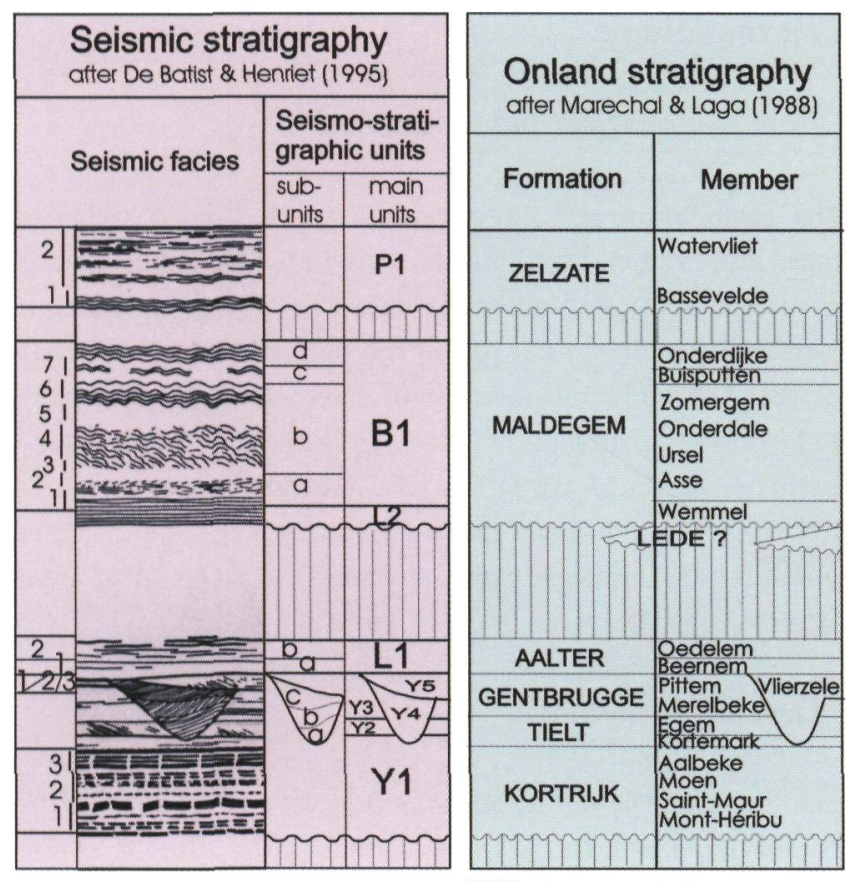

[11] absence of deposits

age, and P1, of Priabonian age. Most of the units have a pronounced sheet-like shape, with horizontal boundaries at their base and top. Localised erosional truncation and valley incisions are common features at the top of the units. Each unit is characterized by a distinct seismic facies and/or by typical facies variations, indicative of the depositional environment and its evolution. The main seismic-stratigraphic characteristics of these units were compiled by Maréchal et al. (1986) and Jacobs \& De Batist (1996) into a synoptic seismic and schematic type section, constructed as a composite of several seismogram sections acquired with comparable source signatures (Fig. 2).

\section{Distribution and geometry of the deposits}

Eocene units gently dip $\left(0.5-1^{\circ}\right)$ towards the NNE, which results in progressively younger strata subcropping below the sub-horizontal base of the Quaternary cover from SW to NE (Fig. 3). The extension and thickness of the Eocene deposits is highly variable within the different geological units (Figs. 3 and 4). Units subcrop along the whole width of the platform, except for units $\mathrm{Y} 4$ and $\mathrm{Y}$, which are confined to a channel or erosional depression cut into units Y1, Y2 and Y3 during an erosion/infilling stage. $\mathrm{Y} 4$ has a maximum thickness of $10 \mathrm{~m}$ and subcrops beneath the Akkaert Bank and the Goote Bank, whereas unit Y5 extends from the coast to the Thornton Bank with a maximum thickness of $17 \mathrm{~m}$ (Fig. 4, top right and bottom right). Unit Y1 subcrops in the major part of the western Belgian continental shelf and displays the largest thickness (150 to $180 \mathrm{~m}$; Fig. 4). The thickness reaches $30 \mathrm{~m}$ in units $\mathrm{Y} 2$ and $\mathrm{Y} 3,45-60 \mathrm{~m}$ in unit $\mathrm{B} 1$ and $40-90 \mathrm{~m}$ in unit L1, maximum to the North of the Noordhinder Bank (Fig. 4).

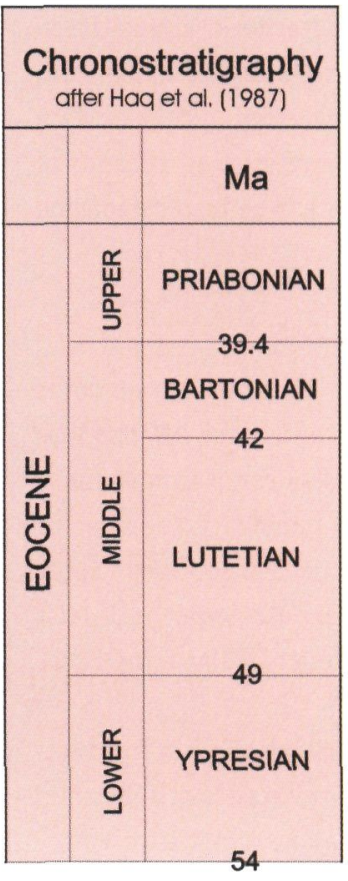

Fig. 2. Eocene seismostratigraphy and onland stratigraphy of the Belgian continental shelf (modified from Jacobs \& De Batist, 1996).

\section{Lithostratigraphy}

Onshore Eocene lithostratigraphy was summarized by Maréchal \& Laga (1988) and Laga et al. (2001). The interpretation of the lithostratigraphy of the offshore seismic-stratigraphic units was carried out by De Batist (1989), De Batist \& Henriet (1995), Jacobs \& Sevens (1993), Jacobs (1995) and Jacobs \& De Batist (1996) based on a correlation between seismic data, 4 offshore boreholes and onshore outcrops. However, knowledge of the lithostratigraphy of offshore Eocene deposits was not very detailed, in particular towards the outer parts of the shelf where only a few cores were available at that time. Major uncertainties also remained in the offshore lithostratigraphy of Eocene deposits, since these deposits are characterized by rapid lateral facies changes related to the marginal position of the area in Eocene times (Jacobs \& De Batist, 1996). Such marginal environments (Table 1) are submitted to a strong variability of sediment sources and depositional processes, inducing rapid changes in sediment nature and pattern (lithological facies) in the across-margin direction (onshore-offshore).

We have been able to access and compile lithological information from in total 33 offshore cores and 165 onshore cone penetration tests, which allowed us to refine the lithostratigraphy of the offshore Eocene units. The new stratigraphy is summarized in Fig. 5.

Most of the offshore units display little across-margin lithological variability. Units Y1 and Y4, and the Ursel, Zomergem and Onderdijke Members (unit B1) consist of clay. The Buisputten Member (unit B1) is composed of sand. The Wemmel, Asse and Onderdale Members (unit B1) consist of clayey sands, and the Kortemark Member (unit Y2) and unit Y3 consist of sandy clay. Some units display a strong lateral lithological 


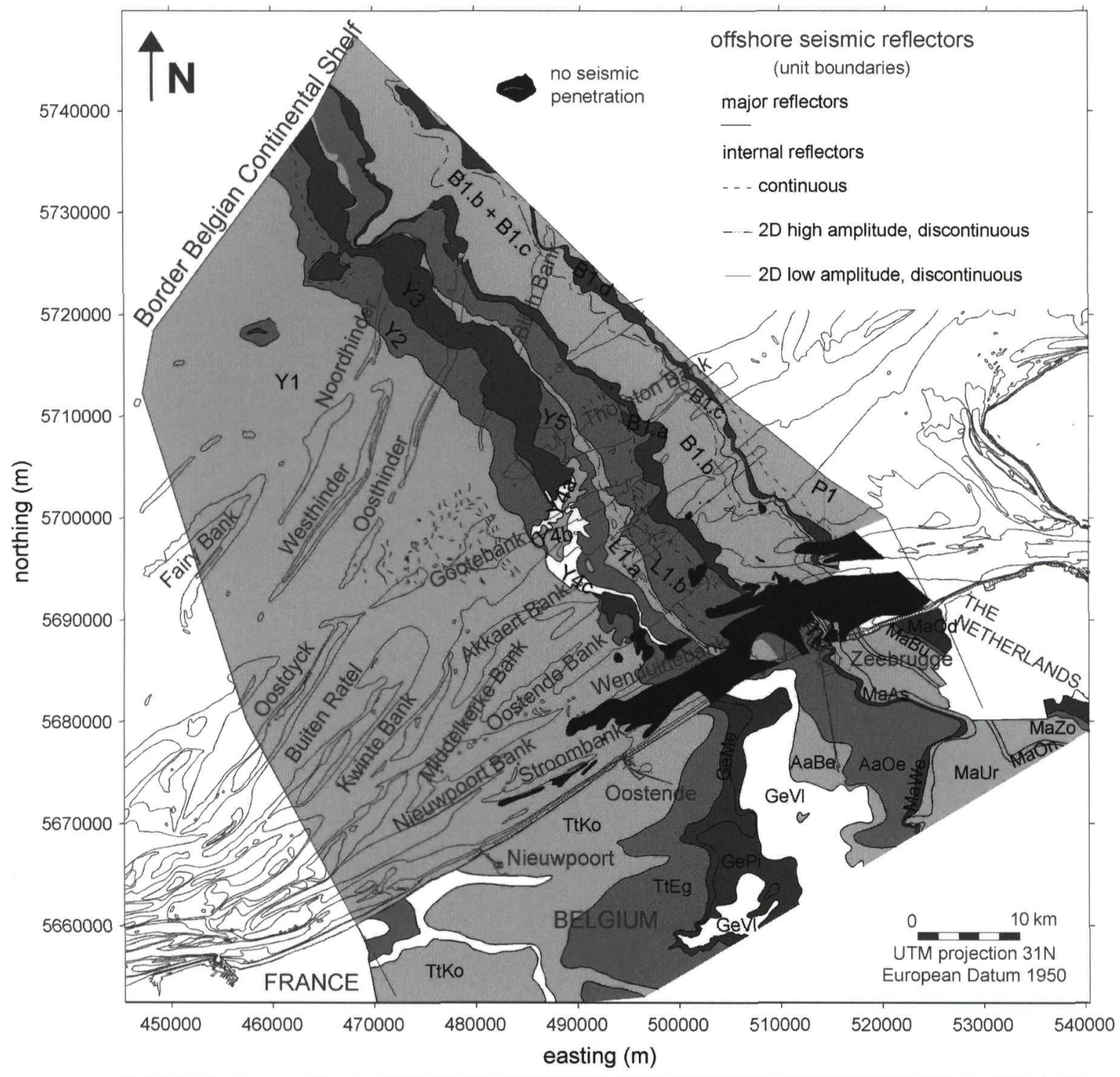

\section{offshore}

Y1: Kortrijk Fm. - Tielt Fm., Kortemark M.

Y2: Tielt Fm., Egem M.

Y3: Gentbrugge Fm., Merelbeke - Pittem M.

Y4.a: Gentbrugge Fm., Vlierzele M. (basal part)

Y4.b: Gentbrugge Fm., Vlierzele M. (basal part)

Y4.c: Gentbrugge Fm., Vlierzele M. (basal part)

Y5: Gentbrugge Fm., Vlierzele M. (upper part)

L1.a: Aalter Fm., Beernem M.

L1.b: Aalter Fm., Oedelem M.

B1.a: Maldegem Fm., Wemmel M.

B1.b: Maldegem Fm., Asse - Ursel - Onderdale - Zomergem M.

B1.c: Maldegem Fm., Buisputten M.

B1.d: Maldegem Fm., Onderdijke M.

P1: Zelzate Fm.

\section{onshore}

TtKo: Tielt Fm., Kortemark M.

TtEg: Tielt Fm., Egem M.

GeMe: Gent Fm., Merelbeke M.

GePi: Gentbrugge Fm., Pittem M.

GeVl: Gentbrugge Fm., Vlierzele M.

AaBe: Aalter Fm., Beernem M

AaOe: Aalter Fm., Oedelem M.

MaWe: Maldegem Fm., Wemmel M.

MaAs: Maldegem Fm., Asse M.

MaUr: Maldegem Fm., Ursel M.

MaOn: Maldegem Fm., Onderdale M.

MaZo: Maldegem Fm., Zomergem M.

MaBu: Maldegem Fm., Buisputten M.

MaOd: Maldegem Fm., Onderdijke M.

Fig. 3. Subcrops of Eocene deposits under the Quaternary deposits (offshore data: compilation after Maréchal et al., 1986; De Batist, 1989; De Batist \& Henriet, 1995 / onland data: Jacobs et al., 2002).

variability, resulting in a distal (i.e. towards the $\mathrm{N}$ and $\mathrm{NE}$ ) fining of sediments. The Egem Member (unit Y2) and unit Y5 consist of sand onshore and evolve offshore towards sandy clay. The Oedelem Member (unit L1) consists of clayey sand onshore (more than $70 \%$ of sand, mean grain-size: $0,08 \mathrm{~mm}$ ) and evolves offshore to silty clay surmounted with a sand layer (11 $\mathrm{m}$ thick) and alternating layers of sandy silty clay and clayey silty sand. These units are associated with coastal environments where rapid changes of sedimentary sources and processes occur. 
Table 1. Depositional environments of the Eocene units of the Belgian continental shelf (modified from Jacobs \& De Batist, 1996).

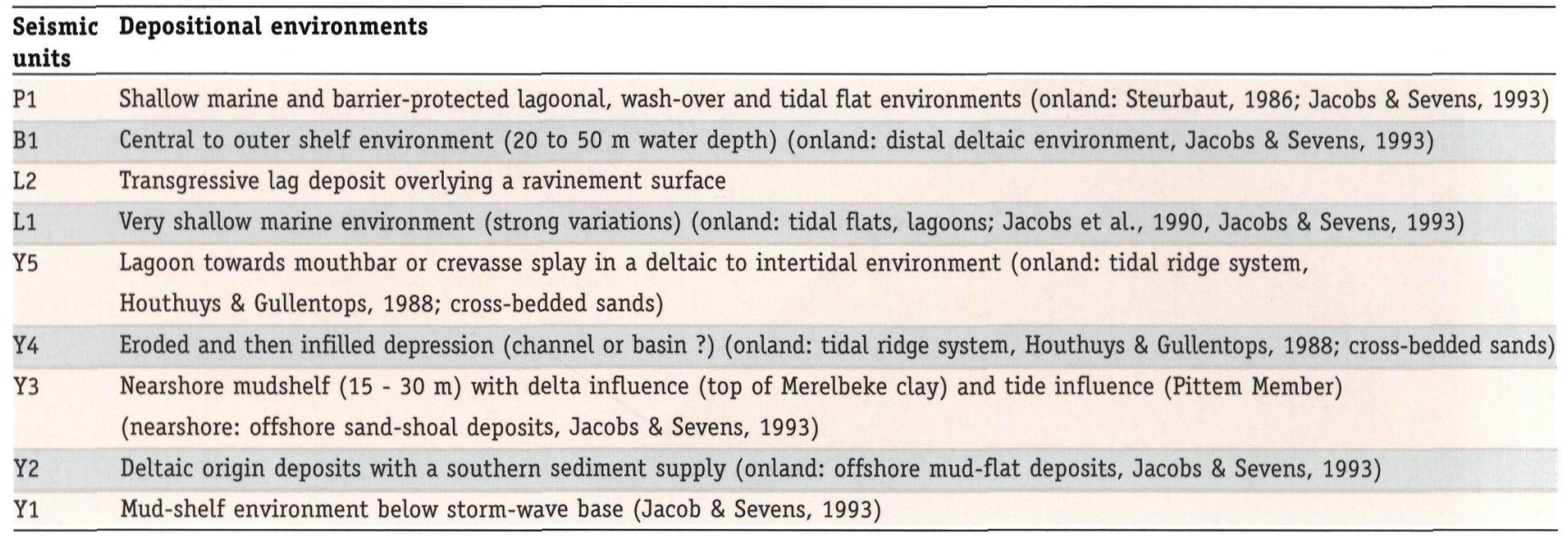

Onshore, the Onderdale, Oedelem, Vlierzele, Pittem and Egem Members, consisting of sand or a mixture of sand and clay, usually display a large variety of cone resistance values (Fig. 6), which underlines the heterogeneity of these deposits, whereas the Kortemark, Merelbeke, Asse, Ursel, Zomergem and Onderdijke Members consist of clayey, more homogeneous units.

Thin hard layers have been observed onshore within the Oedelem Member (unit L1), the Wemmel Member (unit B1) and units Y4, Y5 and L2. They correspond to calcarenite, sandy limestone or sandstone beds. In the 0edelem Member, these beds have been correlated with very high amplitude seismic reflectors (Depret, 1983).

\section{Deformation structures}

On the Belgian continental shelf, two types of deformations are observed. Basement-induced deformations occur in two large areas: i.e. the Noordhinder and the Goote-Raan deformation zones (Fig. 4). Structural features involve faults and folds and are attributed to regional tectonic stresses during late Eocene times. They are no longer active. Sediment-dynamic or -tectonic deformations, now known as polygonal faulting or intraformational faulting, were observed and interpreted for the first time in some clay units of the Belgian continental shelf, such as units Y1 and B1 (Henriet et al., 1982, 1988; De Batist et al., 1989; Cameron et al., 1992). They are attributed to changes in the mechanical and rheological properties of the sediment during compaction (Henriet et al., 1982, 1988; De Batist et al., 1989; Cameron et al., 1992).

\section{Quaternary deposits}

The Quaternary cover is characterized by localized deposits, displaying a laterally and vertically complex and heterogeneous facies assemblage. The distribution of Quaternary deposits is well known, as is their lithostratigraphy in some places, but a lateral correlation of the different isolated Quaternary accumulations is difficult to accomplish.

\section{Main depositional features}

\section{Pleistocene deposits}

On the Belgian continental shelf, only few sediments are considered to be of Pleistocene age. Their scarcity is due to a combined effect of a complete exposure of the Belgian continental shelf during glacial lowstands and an extensive sediment reworking during the Holocene transgression. At the same time, a lack of coring information prevents their mapping. Pleistocene deposits mainly fill scour hollows and palaeovalleys cut into the top of Eocene deposits (Fig. 7). These were probably formed by fluvial erosion and tidal scouring during phases of Late Pleistocene sea-level lowstand and subsequent rise (Liu, 1990; Liu et al., 1993). The scour hollows occur essentially within fluvial palaeovalleys, mainly in the Axial Channel and in the Oostende Valley (Liu et al., 1993). The Sepia Pits 1, 2 and 3 (Mostaert et al., 1989; Liu, 1990), that have been cut $20 \mathrm{~m}$ or more below the base of the 0ostende Valley, are $3-3.5 \mathrm{~km}$ across and accumulate up to $30-40 \mathrm{~m}$ of sedimentary infill. Other Pleistocene deposits, such as channel deposits or marine deposits, not more than $10 \mathrm{~m}$ thick, have been locally observed (Kirby \& 0ele, 1975; Paepe et al., 1981; Baeteman \& Van Strijdonck, 1989; Balson et al., 1992; Baeteman \& Denys, 1997).

\section{Holocene sediments}

Most of the preserved Quaternary sediments have been deposited during the Holocene transgression, when a repeated reworking and removal of the material led to the deposition of the Young Sands on top of tidal flat deposits, estuarine sand banks and beach deposits (Oele \& Schüttenhelm, 1979; Jelgersma et al., 1979; Jansen et al., 1979; Baeteman \& Denys, 1997). These sands took part in the development of the presentday sand banks, which form the thickest accumulations of Quaternary deposits and the most prominent seabed features on the Belgian continental shelf (Fig. 7). The seismic and 


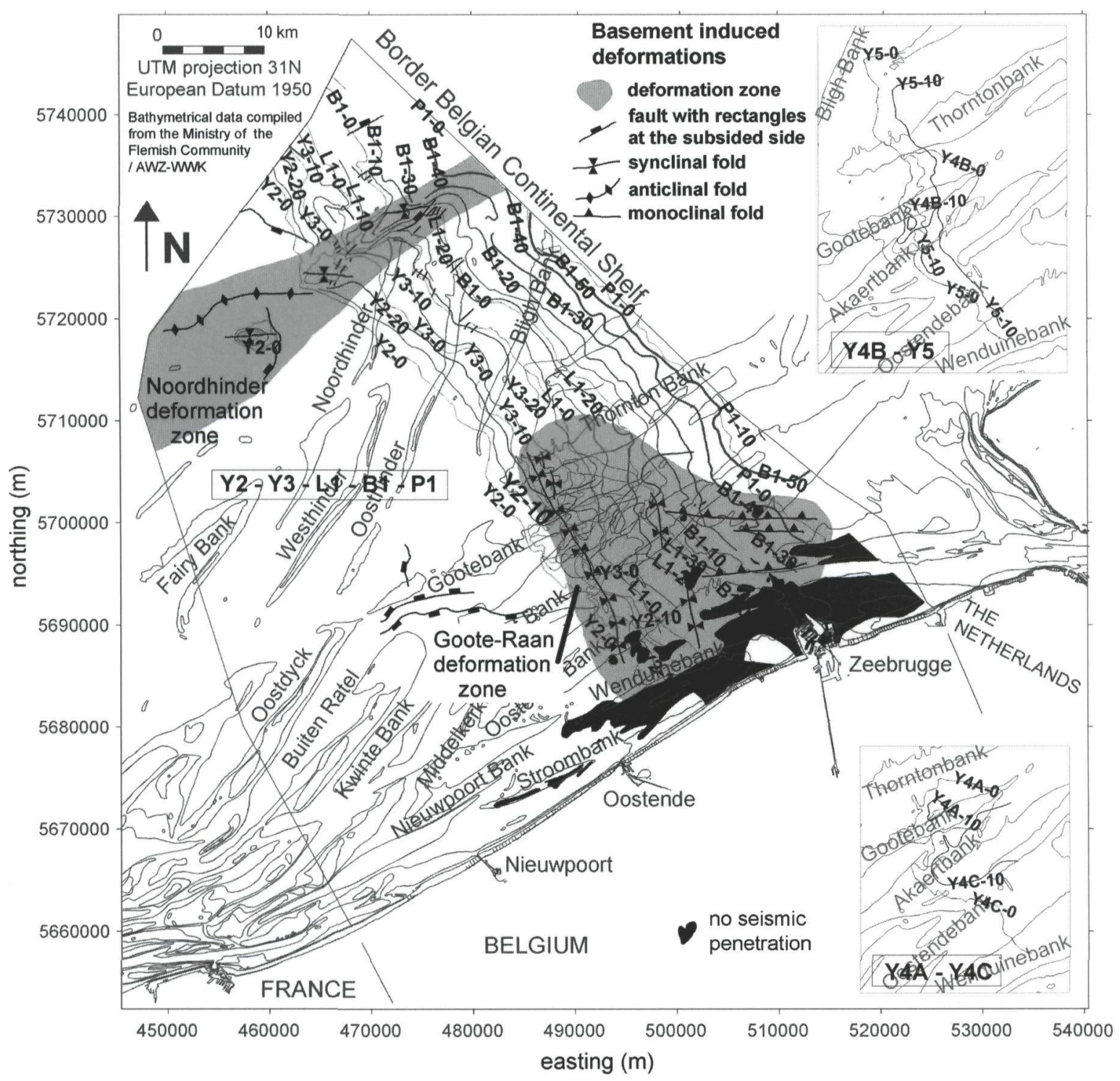

Fig. 4. Thickness of Eocene deposits and regional deformations (after

Distribution and geometry of the deposits

De Batist, 1989). Isopachs with thickness in metres.

lithostratigraphy of several sand banks has been investigated: i.e. the Akkaert Bank, the Goote Bank, the Thornton Bank and the Vlakte van de Raan (Maréchal et al., 1986), the Kwinte Bank (De Moor, 1986), the Western Coastal Banks (De Maeyer et al., 1985; Wartel, 1989). Within the Middelkerke Bank, intensively studied during the EC MAST projects RESECUSED and STARFISH (De Moor \& Lanckneus, 1993; Trentesaux, 1993; Trentesaux et al., 1994; Berné et al., 1994; Heyse \& De Moor, 1996; Trentesaux et al., 1999), 7 Holocene seismic-stratigraphic units were identified on top of an incised channel, which was cut into the underlying Eocene strata during Weichselian times (Trentesaux, 1993).

Recent tidal currents have also shaped nearly planar beds and dunes (Eisma et al., 1979). Peat layers are observed in coastal areas and in Pleistocene paleovalleys (Baeteman \& Van Strijdonck, 1989; Baeteman \& Denys, 1997).

On the Belgian continental shelf the base of Quaternary deposits coincides with the erosional surface, which truncates the Eocene sequence (Mostaert et al., 1989). The base of the Quaternary is affected by numerous and various morphological features, such as scour hollows, valleys, scarps, slope breaks and cuestas (Liu et al., 1992). It deepens progressively from $12.5 \mathrm{~m}$ at the coast to $60 \mathrm{~m}$ in the outer parts of the shelf, and locally displays larger depths beneath scour hollows and paleovalleys.

The thickness of the Quaternary sediments ranges from a few to $50 \mathrm{~m}$ (Fig. 7). Locally, Eocene strata are exposed at the seabed, where they even can be eroded by the present-day currents. In most of the swales between sand banks, the Quaternary thickness is between 0 and $10 \mathrm{~m}$ and mostly less than 2.5 m (Maréchal \& Henriet, 1983; Maréchal et al., 1986). The largest thicknesses are reached in the tidal Holocene sand banks (up to $30 \mathrm{~m}$ ) and in the Pleistocene scour hollows (e.g. $40 \mathrm{~m}$ in Sepia Pit 1 beneath the 0ostende Bank). 


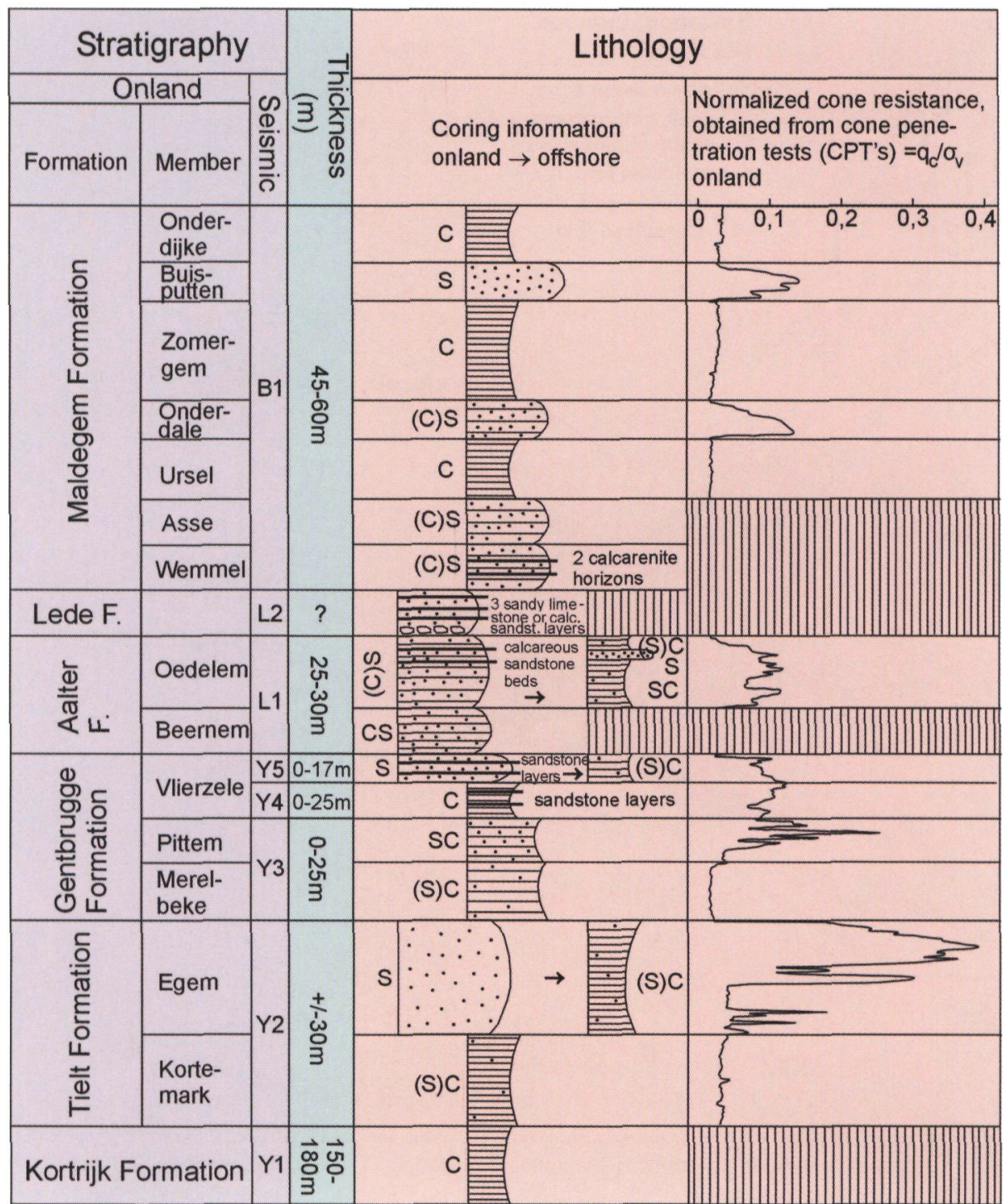

Elay - C $\therefore$ : Sand - S
Thin hard layers
마 Pebbles 민 No data
Fig. 5. Lithostratigraphy of Eocene deposits. Synthetic logs compiled from onland to offshore coring information (left) and onland typical normalized cone resistance parameter profiles (right). On a depth basis, correlation has been realised between coring and seismo-stratigraphic information, and coring and cone resistance information.

\section{Lithostratigraphy}

Quaternary sediments are highly heterogeneous and display a complex distribution pattern. This stands in contrast to the more regular trends in the Eocene deposits. Vertical and lateral heterogeneity is visible on cone penetration test profiles as well as in cores. According to coring data, the Quaternary sediments consist mainly of medium coarse to very coarse sands (generally $60-65 \%$ of sand and a mean grain-size between 0.2 and $0.45 \mathrm{~mm}$ ) with intercalation of shelly, gravelly (flints) and clayey layers.

\section{Present-day seabed}

\section{Seabed morphology}

The seabed of the Belgian continental shelf deepens offshore to a depth of about $50 \mathrm{~m}$ (MLLWS datum) (Fig. 8). In the 10 to $20 \mathrm{~km}$-wide coastal zone, including the Coastal Banks and the Vlakte van de Raan, the depth rapidly increases from 0 to $15 \mathrm{~m}$. In the central part, in between the major bedforms (i.e. the Flemish Banks, the Zeeland Ridges, the Hinder Banks), the depth varies between 15 and $35 \mathrm{~m}$. In the northernmost part, where no sand banks occur, depths of 35 to $50 \mathrm{~m}$ are reached.

Sand banks are the largest type of bedforms observed on the Belgian continental shelf. They are up to $30 \mathrm{~m}$ high, several tens of kilometres long and several kilometres wide. They culminate only a few meters below sea level. Sand banks are mostly covered with dunes (Fig. 9). The largest superimposed dunes are mostly observed on the gentle flanks of sand banks and in their non-linear parts, especially at the northern extremity of the Flemish Banks and in the region of the Hinder Banks (Deleu et al., 2004). Fields of dunes are also observed on the flatter parts of the seabed. They are mainly up to $4 \mathrm{~m}$ high, but can reach heights of $11 \mathrm{~m}$ in the swales in the northern part of the Hinder Banks. A synthesis of the characteristics of the bedforms occurring on the Belgian continental shelf and a map of their distribution can be found in Lanckneus et al. (2001). 


\section{Seabed sediments}

The Belgian continental shelf is mainly covered with fine to coarse sands (Balson et al., 1992; Lanckneus et al., 2001). In the coastal area, from 0ostende to the Dutch border, sediments mainly consist of fine sands with a variable mud enrichment. Lag gravel deposits have been observed in many of the swales between sand banks, especially in the area of the Hinder Banks (Lanckneus et al., 2001), and can generally be expected in areas where the Quaternary cover is thin. An overview of the spatial distribution of the seabed sediments and their characteristics can be found in Lanckneus et al. (2001).

\section{Bedform dynamics}

Sandbanks bear witness to a major stability phase at least since the last 200 years, except the features under the influence of the Westerschelde Estuary and the youngest sand bodies (Van

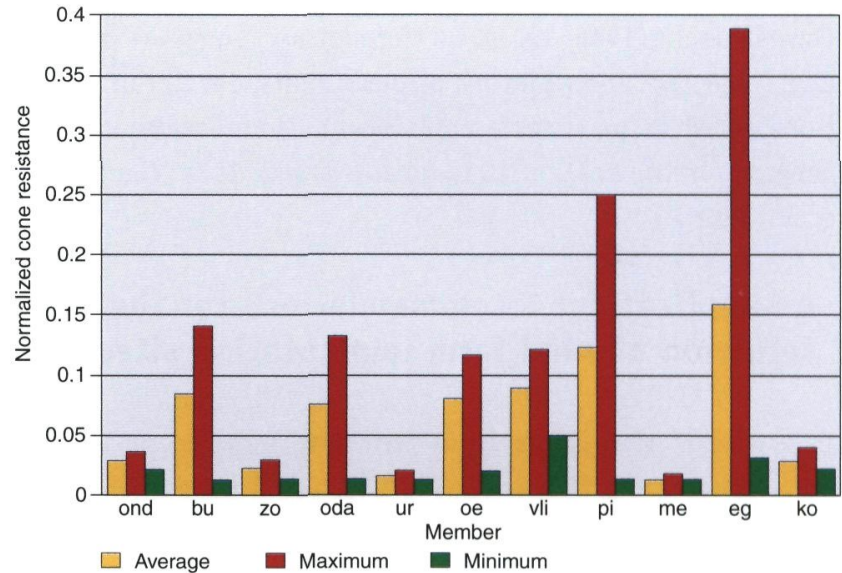

Fig. 6. Values of normalized cone resistance for every stratigraphic member. Average, maximum and minimum values from cone penetration tests. ond: Onderdijke; bu: Buisputten; zo: Zomergem; oda: Onderdale; ur: Ursel; oe: Oedelem; vli: Vlierzele; pi: Pittem; me: Merelbeke; eg: Egem; ko: Kortemark.

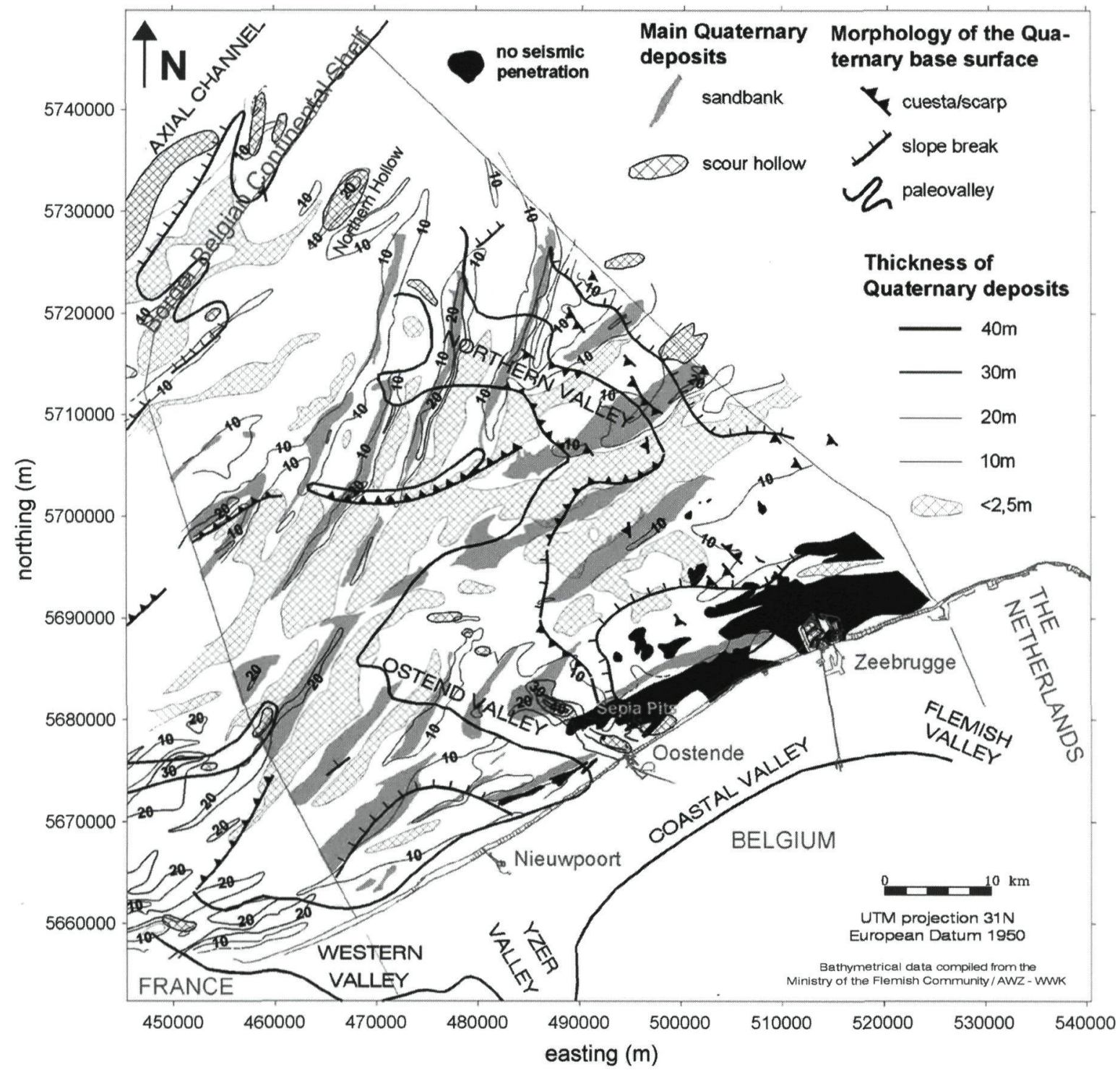

Fig. 7. Quaternary thickness with location of the main deposits (sandbanks and scour hollows) (compilation after: Liu, 1990; Liu et al., 1992). 
Cauwenberghe, 1966, 1971). On the contrary, dunes are dynamic and subjected to oscillatory displacements. In stormy conditions or when persistent winds occur, these movements are generally in the order of $20 \mathrm{~m}$ for the largest dunes (Lanckneus et al., 2001).

\section{An application: recommendations for the selection of wind farm implantation sites}

In the view of offshore wind farm implantation, a detailed knowledge of the geology and geotechnical properties of the Eocene and Quaternary deposits and the present-day seabed sediments is very important. These parameters determine to what extent sites may meet the criteria of seabed stability and where there will be minimal environmental impacts on the seabed.

\section{Stability and environmental criteria}

An offshore wind farm consists of several wind turbines mounted on piles. A system of submarine high-voltage electrical cables interconnects the individual turbines and the whole wind farm to the onshore electrical network. In general, the substrate and seabed properties are significant only for the foundations and the cables. Two main types of foundations can be dis- tinguished (CA-OWEE, 2002): (1) foundations driven some 10 to $20 \mathrm{~m}$ into the seabed and the solid substratum, such as the monopiles ( $3-3.5 \mathrm{~m}$ in diameter) that are currently used in water depths up to $20 \mathrm{~m}$; (2) foundations put on the seabed, such as gravity structures (e.g. concrete or steel caissons of 12 - $15 \mathrm{~m}$ in diameter) that are currently used in shallow waters (less than $10 \mathrm{~m}$ depth).

Foundations provide support to the wind mill structures submitted to loads by restricting settlement and avoiding failure by ground rupture. The pile capacity can be evaluated from cone penetration tests which act as a model pile test. In particular, the cone resistance, obtained from cone penetration tests, may be used to estimate end bearing (Hunt, 1986; Budhu, 1999). Loads acting on piles consist of: (1) vertical loads, induced by the weight of the turbine and the equipment, and (2) horizontal loads, mainly dynamic in offshore environments, induced by waves, tidal currents, winds and dynamic bedforms. The horizontal loads are one order of magnitude larger than the vertical loads. Scouring phenomena can also lead to major instability of the structures, especially around the large gravity foundations.

Submarine cables are generally about $10 \mathrm{~cm}$ in diameter and buried in the seabed. Cables are exposed to damage from anchoring and trawling as well as from natural bedform migration. For $90 \%$ of the cable routes where damage to cables is

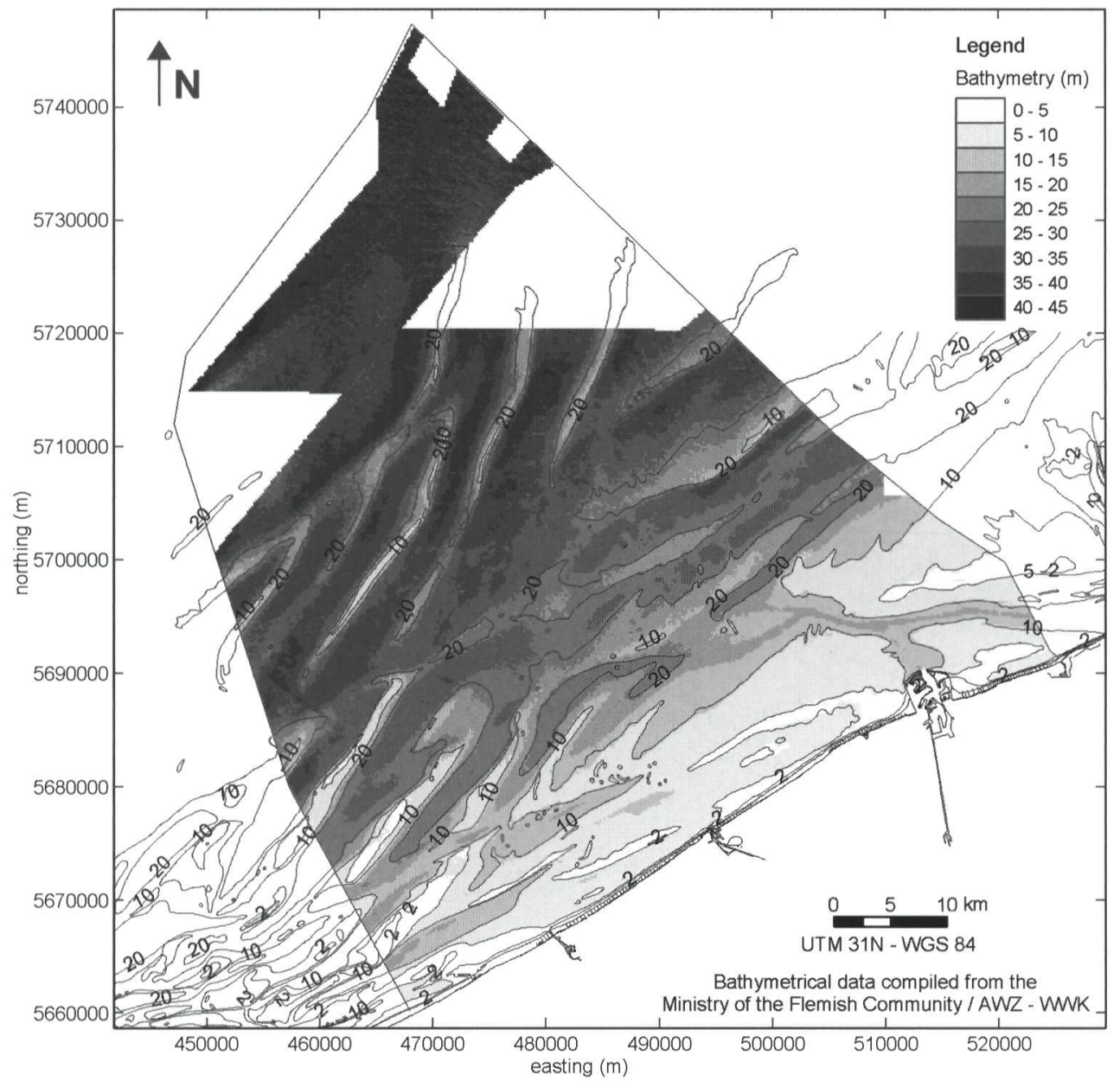

Fig. 8. Pseudo 3D image of the topography of the Belgian continental shelf based on single-beam echosounder data (compiled from the Flemish Community AWZ-WWK Zeebrugge) (after Lanckneus et al., 2001). The sandbanks are the prominent seabed features and dunes appear as rough and mottled areas. 


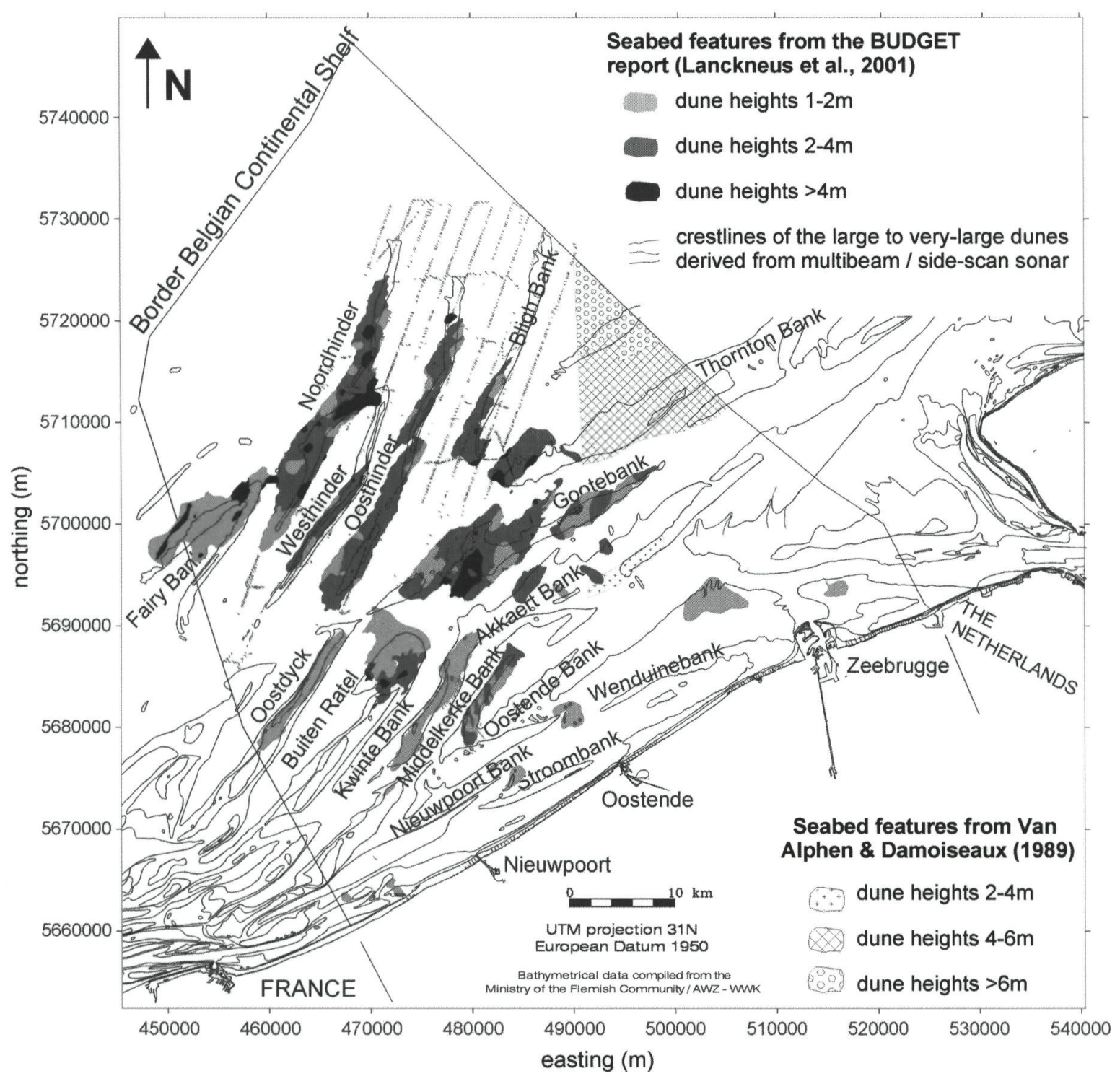

Fig. 9. Dunes areas with indication of heights (compilation from Van Alphen \& Damoiseaux, 1989, for the Zeeland Ridges, and Lanckneus et al., 2001). The available information is largely restricted to the sandbank areas.

likely, trenching and burial is the best long-term solution to cable protection (Shaw, 2001). Cone penetration test results can also be used to derive design conditions for the top 0.1 to $1 \mathrm{~m}$ of the seabed (Lunne et al., 1997, in Whitehouse et al., 2000).

Table 2 summarizes the different mechanisms and parameters which have to be investigated to assess the stability potential for structures. As far as substrate properties are concerned, the most suitable geological layers consist of: (1) the most compacted and homogeneous layers; (2) the layers having a high shear stress and a good long-term behaviour. Suitable layers should have a sufficient thickness as well to cope with failure mechanism. As far as seabed conditions are concerned, the most suitable places correspond to the less dynamic ones. In case of gravity foundations, the selected site is preferably smooth and devoid of pebbles.

\section{Site recommendations}

A geological and geotechnical classification of sites suitable for offshore wind farm implantation is difficult to establish since this will vary considerably according to the type of wind farm structure concerned (pile or cable), the type of foundation chosen (piled structures or gravity based foundations) but also the budget constraints. Moreover, producing a detailed suitability map (with indication of the most and less suitable sites) for the entire Belgian continental shelf is also not realistic, given (1) the heterogeneity and variability of substrate and seabed properties, mainly from a lithological and geotechnical point of view, and (2) the scarcity of this type of offshore data.

Nevertheless, general mapping combinations of relevant geoparameters from the currently available datasets can be used to identify areas that have potentially suitable properties for installation of offshore wind farm structures. For the case of monopile structures (Fig. 10), the Eocene sandy deposits are more suitable than: (1) Eocene clayey deposits, which present a low shear strength and a bad long-term behaviour; (2) 
Table 2. Mechanisms and parameters to be investigated to ensure the stability of offshore windmill structures.

\begin{tabular}{|c|c|c|}
\hline Structures & Mechanisms & Parameters \\
\hline \multirow{3}{*}{$\begin{array}{l}\text { Foundations } \\
\text { (in general) }\end{array}$} & \multirow[t]{2}{*}{ General stability (exploitation phase) } & Load capacity, settlement (point resistance, friction resistance, angle \\
\hline & & of internal friction, shear strength) \\
\hline & Loading (exploitation phase) & Sediment dynamics (transport rates, scouring, bedform migration) \\
\hline Foundation & \multirow{4}{*}{$\begin{array}{l}\text { Drivability of pile (construction phase) } \\
\text { settlement (exploitation phase) }\end{array}$} & Geology of the solid substrate (nature, depth, thickness, homogeneity \\
\hline driven into & & of geological layers) \\
\hline \multirow[t]{2}{*}{ the seabed } & & Solid substrate geotechnics (shear strength, local friction, point \\
\hline & & resistance, undrained cohesion, bearing layer) \\
\hline Foundation put & \multirow[t]{2}{*}{ Smoothing of the seabed (construction phase) } & Seabed sediments (nature and grain-size) \\
\hline on the seabed & & Seabed morphology (slope, bedforms, rock outcrops) \\
\hline \multirow[t]{2}{*}{ Submarine cables } & \multirow{2}{*}{$\begin{array}{l}\text { Trench construction and infilling problems } \\
\text { (construction phase) }\end{array}$} & Seabed sediments (thickness, nature, grain-size) \\
\hline & & Sediment dynamics (transport rates) \\
\hline
\end{tabular}

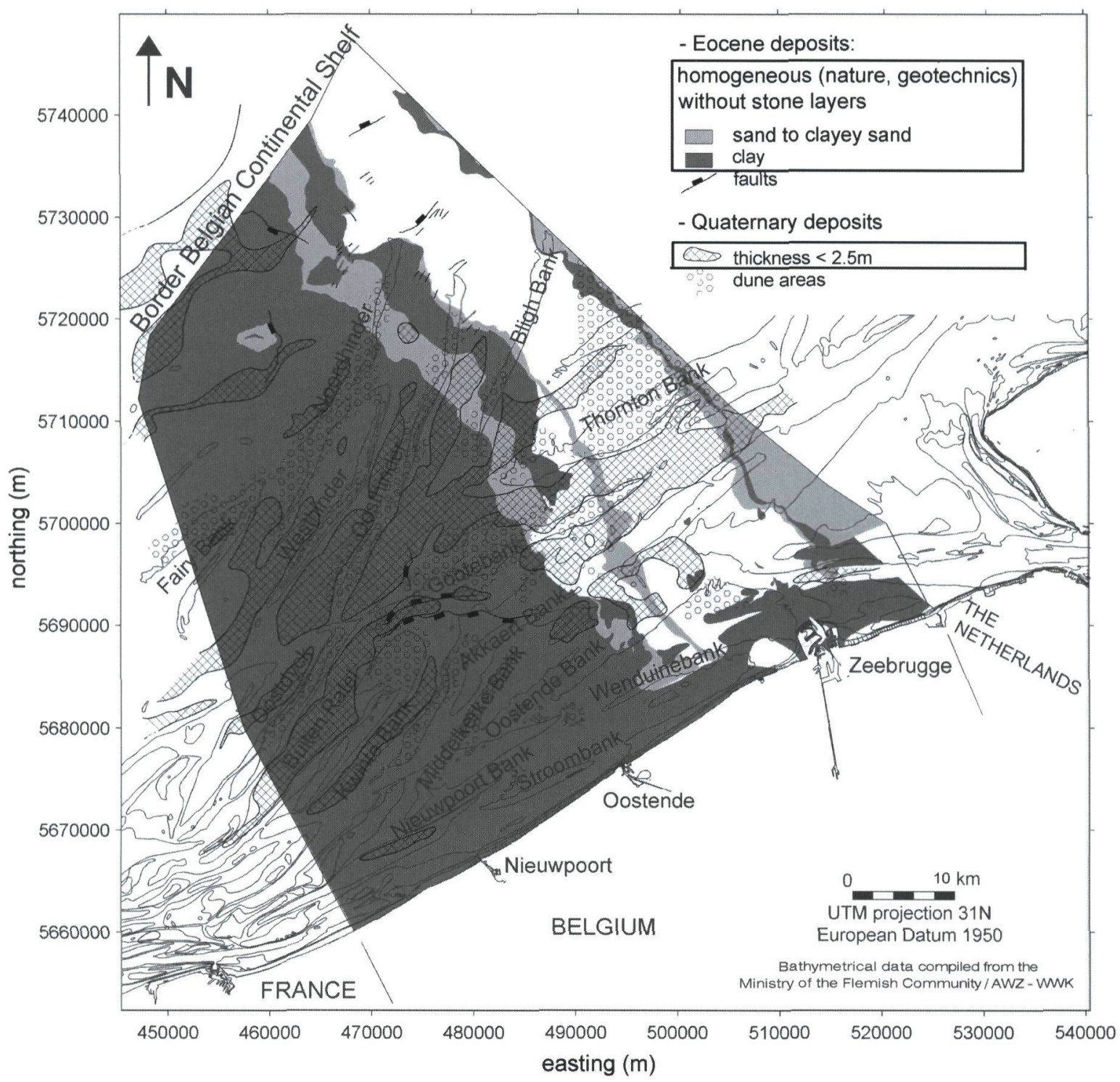

Fig. 10. Most and less suitable sites for wind farm implantation in case of monopile structures. Mapping scenario proposed from the combinations of various relevant geo-parameters. The water depth parameter is not specifically focused on. In the top legend, the rectangles indicate the most suitable geological and geotechnical conditions; the other criteria correspond to less suitable ones. In the eastern part, the white areas are also less suitable because of the presence of stony layers in the subsoil. 
Quaternary sandy deposits, such as sand banks and scour hollows, which are less compacted and lithologically highly complex and heterogeneous. Eocene layers affected by regional deformations, or containing hard calcareous or sandstone layers have to be avoided, given their heterogeneity. Interesting sites could correspond to areas with a minimal Quaternary cover, where the Eocene layers have the largest amount of sand and are devoid of deformations, and sufficiently thick, given the length of the pile. As far as seabed conditions are concerned, flat areas would be preferred over dynamic sandy bedforms. Since water depth is a major criterion for the cost of structures, moderate water depths are generally preferred (up to $20 \mathrm{~m}$, Van Hulle et al., 2004). In that case, on the Belgian continental shelf, the older and larger stable offshore sand banks or the area of dunes with a very small net migration rate should be preferred, to limit high horizontal loads and pronounced scouring processes.

It should, however, be kept in mind that a detailed geological and geotechnical site investigation still remains indispensible for each site proposed for wind farm implantation, in order to verify the local characteristics of the specific site.

\section{Acknowledgments}

The authors acknowledge the Belgian Science Policy Office for the financial support to the project '0ptimal Offshore Wind Energy Developments in Belgium' (CP/H8/211), in the framework of which the present synthesis has been conducted. 'Databank Ondergrond Vlaanderen' of the Ministry of the Flemish Community and the 'Research Unit of Sedimentary Geology' from Ghent University (Prof. P. Jacobs) are especially acknowledged for providing the cone penetration test data, and the Belgian (BGD, Dr. C. Baeteman) and Dutch (TNO-NITG, Dr. C. Laban) Geological Surveys for providing borehole and coring information. The authors gratefully acknowledge M. De Ceukelaire and Dr. F. Mostaert for their pertinent comments on the geological and geotechnical synthesis.

\section{References}

Baeteman, C. \& Van Strijdonck, M., 1989. Radiocarbon dates on peat from the Holocene coastal deposits in West Belgium. In: Baeteman, C. (ed.): Quaternary sea-level investigations from Belgium. Ministerie van Economische Zaken, Geologische Dienst van België (Brussel): 59-91.

Baeteman, C. \& Denys, L., 1997. Holocene shoreline and sea-level data from the Belgian coast. Paleoclimate Research 21: 49-74.

Balson, P.S., Laban, C., Schüttenhelm, R.T.E., Baeteman, C. \& Paepe, R., 1992. Ostend. Sheet $51^{\circ} \mathrm{N}-02^{\circ} \mathrm{E}$. Quaternary geology. 1:250 000 map series. BGS, RGD, BGD.

Berné, S., Trentesaux, A., Stolk, A., Missiaen, T. \& De Batist, M., 1994. Architecture and long term evolution of a tidal sandbank: the Middelkerke Bank (southern North Sea). Marine Geology 121: 57-72.

Budhu, M., 1999. Soil mechanics and foundations. John Wiley \& Sons (New York): $586 \mathrm{pp}$.
Cameron, T.D.J., Crosby, A., Balson, P.S., Jeffery, D.H., Lott, G.K., Bulat, J. \& Harrison, D.J., 1992. United Kingdom Offshore Regional Report: the Geology of the Southern North Sea. HMSO for the British Geological Survey (London).

CA-OWEE, 2002. Technology of OWE. www.offshorewindenergy.org.

De Batist, M., 1989. Seismo-stratigrafie en Struktuur van het Paleogeen in de Zuidelijke Noordzee. PhD Thesis Thesis, Rijksuniversiteit Gent: 107 pp.

De Batist, M., De Bruyne, H., Henriet, J.P. \& Mostaert, F., 1989. Stratigraphic analysis of the Ypresian off the Belgian coast. In: Henriet, J.P. \& De Moor, G. (ed.): The Quaternary and Tertiary Geology of the Southern Bight, North Sea. Belgian Geological Survey (Brussels): 75-88.

De Batist, M. \& Henriet, J.P., 1995. Seismic sequence stratigraphy of the Palaeogene offshore of Belgium, southern North Sea. Journal of the Geological Society of London 152: 27-40.

Deleu, S., Van Lancker, V., Moerkerke, G. \& Vanden Eynde, D., 2004. Morphodynamic evolution of the kink of an offshore tidal sandbank: the Westhinder Bank (Southern North Sea). Continental Shelf Research 24: 1587-1610.

De Maeyer, P., Wartel, S. \& De Moor, G., 1985. Internal structures of the Nieuwpoort Bank, Southern North Sea. Netherlands Journal of Sea Research 19 (1): 15-18.

De Moor, G., 1986. Geomorfologisch onderzoek op het Belgisch Continental Plat. Tijdschrift van de Belg. Ver. Aardr. Studies BEVAS 2: 133-174.

De Moor, G. \& Lanckneus, J., 1993. Sediment mobility and morphodynamics of the Middelkerke Bank. Final report MAST Project-0025-C: Relationship between seafloor currents and sediment mobility in the southern North Sea. University Ghent, RUMACOG: 255 pp.

Depret, M., 1981. Lithostratigrafie van het Kwartair en van het Tertiaire substraat te Zeebrugge. Lithologische en stratigrafische interpretatie van diepsonderingen met de konus van Begemann. Onuitgegeven doktoraatsthesis, Rijksuniversiteit Gent: 338 pp.

Depret, M., 1983. Studie van de lithostratigrafie van het Kwartiair en van het Tertiaire substraat te Zeebrugge onder meer met diepsonderingen, Belgische Geologische Dienst.

Eisma, D., Jansen, J.H.F. \& Van Weering, T.C.E., 1979. Sea-floor morphology and recent sediment movement in the North Sea. In: 0ele, E., Schüttenhelm, R.T.E., \& Wiggers, A.J. (eds): The Quaternary history of the North Sea. Acta of Symposium Annum Quingentesimum Celebrantis (Upsala) 2: 217-232.

Henriet, J.P., D'Olier, B., Auffret, J.P. \& Andersen, N.L., 1982. Seismic tracking of geological hazards related to clay tectonics in the Southern Bight of the North Sea. Symposium Engineering in Marine Environment, K VIV (Brugge): 1.5-1.15.

Henriet, J.P., De Batist, M., Van Vaerenbergh, W. \& Verschuren, M., 1988. Seismic facies and clay tectonics features of the Ypresian clay in the Southern North Sea. Bulletin van de Belgische Vereniging voor Geologie / Bulletin de la Société Belge de Géologie 97: 457-472.

Heyse, I. \& De Moor, G., 1996. Sediment transport and bedform mobility in a sandy shelf environment (STARFISH). Final report, University of Ghent, Research Unit of Marine and Coastal Geomorphology.

Houthuys, R. \& Gullentops, F., 1988. The Vlierzele Sands (Eocene, Belgium): a tidal ridge system. In: De Boer, P.L., Van Gelder, A. \& Nio, S.D. (ed.): Tideinfluenced sedimentary environments and facies. D. Reidel Publishing Company (Dordrecht): 139-152.

Hunt, R.E., 1986. Geotechnical Engineering analysis and evaluation. McGrawHill Book Company (New York): 729 pp. 
Jacobs, P., 1995. Eocene to early Oligocene deltas in the Southern North Sea Bight, Belgium. In: 0ti, M. \& Postma, G. (ed.): Geology of deltas. Balkema (Rotterdam): 139-152.

Jacobs, P. \& Sevens, E., 1993. Eocene siliciclastic continental shelf sedimentation in the Southern Bight North Sea, Belgium. Progress in Belgian Oceanographic Research, Royal Academy of Belgium (Brussels): 95-118.

Jacobs, P. \& De Batist, M., 1996. Sequence stratigraphy and architecture on a ramp-type continental shelf: the Belgian Palaeogene. In: De Batist, M. \& Jacobs, P. (ed.): Geology of the Siliciclastic Shelf Seas. Geological Society, Special Publication 117: 23-48.

Jacobs, P., Sevens, E., De Batist, M. \& Henriet, J.P., 1990. Grain-size, facies and sequence analysis of West Belgian Eocene continental shelf deposits. Zentralblatt für Geologie und Paläontologie, Teil I 8: 931-955.

Jacobs, P., De Ceukelaire, M., Moerkerke, G. \& Polfliet, T., 2002. Toelichtingen bij de geologische kaart. 1:50.000. Kaartblad Blankenberge - Westkapelle Oostduinkerke - Oostende (4-5-11-12). Ministerie van Economische Zaken Belgische Geologische Dienst, Ministerie van de Vlaamse Gemeenschap Afdeling Natuurlijke Rijkdommen en Energie (Brussel).

Jansen, J.H.F., Van Weering, T.C.E. \& Eisma, D., 1979. Late Quaternary sedimentation in the North Sea. In: Oele, E., Schüttenhelm, R.T.E. \& Wiggers, A.J. (ed.): The Quaternary history of the North Sea. Acta University of Upsala Symposium Annum Quingentesimum Celebrantis (Upsala): 175-188.

Jelgersma, S., Oele, E. \& Wiggers, A.J., 1979. Depositional history and coastal development in the Netherlands and the adjacent North Sea since the Eemian. In: Oele, E., Schüttenhelm, R.T.E. \& Wiggers, A.J. (eds): The Quaternary history of the North Sea, Acta University of Upsala Symposium Annum Quingentesimum Celebrantis (Upsala): 115-142.

Kirby, R. \& Oele, E., 1975. The geological history of the Sandettié-Fairy Bank area, southern North Sea. Philosophical Transactions of the Royal Society of London A279: 257-267.

Laga, P., Louwye, S. \& Geets, S., 2001. Palaeogene and Neogene lithostratigraphic units (Belgium). In: Bultynck, P. \& Dejonghe, L. (ed.): Lithostratigraphic scale of Belgium. Geologica Belgica 4 (1-2): 135-152.

Lanckneus, J., Van Lancker, V., Moerkerke, G., Van den Eynde, D., Fettweis, M., De Batist, $M$. \& Jacobs, $P$., 2001. Investigation of the natural sand transport on the Belgian continental shelf (BUDGET). Final report. Federal office for Scientific, Technical and Cultural Affairs (OSTC): 104 pp. + Annex 87 pp.

Liu, A.C., 1990. A seismic and geomorphological study of the erosion surface at the top of the Tertiary in the Southern North Sea (Belgian and Northern French sectors). Unpublished doctoral thesis, Gent University, vol. 1: $119 \mathrm{pp}$. + vol. 2: 97 fig.

Liu, A.C., Missiaen, T. \& Henriet, J.P., 1992. The morphology of the TopTertiary erosion surface in the Belgian sector of the North Sea. Marine Geology 105: 275-284.

Liu, A.C., De Batist, M., Henriet, J.P. \& Missiaen, T., 1993. Plio-Pleistocene scour hollows in the Southern Bight of the North Sea. Geologie en Mijnbouw 71: 195-204.

Lunne, T., Robertson, P.K. \& Powell, J.J.M., 1997. Cone penetration testing in geotechnical practice. Taylor \& Francis Group (London): 312 pp.

Maréchal, R. \& Henriet, J.P., 1983. Seismisch onderzoek op het Belgisch Continentaal Plat. Eerste fase. Ontginningszone 2. Onuitgegeven Rapport, Ministerie voor Economische Zaken: 32 pp.
Maréchal, R., Henriet, J.P., Mostaert, F., De Batist, M., Moons, A. \& Verschuren, M., 1986. Studie oppervlaktelaag van het Belgisch Continentaal Plat. Seismisch prospectie sector B. Onuitgegeven Rapport, Ministerie voor Economische Zaken: $52 \mathrm{pp.}$

Maréchal, R. \& Laga, P., 1988. Voorstel lithostratigrafische indeling van het Paleogeen. Nationale Commissies voor Stratigrafie - Commissie Tertiair, Unpublished Report.

Mostaert, F., Auffret, J.P., De Batist, M., Henriet, J.P., Moons, A., Sevens, E., Van Den Broeke, I. \& Verschuren, M., 1989. Quaternary shelf deposits and drainage patterns off the French and Belgian coasts. In: Henriet, J.P. \& De Moor, G. (ed.): The Quaternary and Tertiary Geology of the Southern Bight, North Sea. Belgian Geological Survey: 111-118.

Oele, E. \& Schüttenhelm, R.T.E., 1979. Development of the North Sea after the Saalian glaciation. In: 0ele, E., Schüttenhelm, R.T.E. \& Wiggers, A.J. (eds): The Quaternary history of the North Sea. Acta University of Upsala Symposium Annum Quingentesimum Celebrantis (Upsala): 191-216.

Paepe, R.C., Baeteman, C., Mortier, R. \& Vanhoorne, R., 1981. The marine Pleistocene sediments in Flanders area. Geologie en Mijnbouw 60: 321-330.

Shaw, 2001. Cable protection: a rationale. Poster presentation. Offshore Wind Energy, Special Topic Conference, EWEA (Brussels), 10 - 12 December 2001.

Steurbaut, E., 1986. Late Middle Eocene to Middle Oligocene calcareous nannoplankton from the Kallo well, some boreholes and exposures in Belgium and a description of the Ruisbroek Sand Member. Mededelingen van de Werkgroep Tertiaire en Kwartaire Geologie 23: 49-83.

Trentesaux, A., 1993. Structure et dynamique sédimentaire du Middelkerke Bank, Mer du Nord méridionale. PhD Thesis, University of Lille 1: $229 \mathrm{pp}$.

Trentesaux, A., Stolk, A., Tessier, B. \& Chamley, H., 1994. Surficial sedimentology of the Middlekerke Bank (southern North Sea). Marine Geology 121: 43-55.

Trentesaux, A., Stolk, A. \& Berné, S., 1999. Sedimentology and stratigraphy of a tidal sand bank in the southern North Sea. Marine Geology 159: 253-272.

Van Cauwenberghe, C., 1966. Hydrografische analyse van de Scheldemonding ten oosten van de Meridiaan $3^{\circ} 05^{\prime}$ tot Vlissingen. Het Ingenieursblad 40 (19): 563-571.

Van Cauwenberghe, C., 1971. Hydrografische analyse van de Vlaamse banken langs de Belgische-Franse kust. Ingenieurstijdingen Blatt 20: 141-149.

Van Alphen, J.S.L.J. \& Damoiseaux, M.A., 1989. A geomorphological map of the Dutch shoreface and adjacent part of the continental shelf. Geologie en Mijnbouw 68: 433-443.

Van Hulle, F., Le Bot, S., Cabooter, Y., Soens, J., Van Lancker, V., Deleu, S., Henriet, J.P., Palmers, G., Dewilde, L., Driesen, J., Van Roy, P. \& Belmans, R., 2004. Optimal offshore wind energy developments in Belgium. Federal Science Policy Office, SPSDII. Scientific Support Plan for a Sustainable Development Policy, Part I. Sustainable Production and Consumption Patterns. Energy (D/2004/1191/17) (Brussels): 153 pp.

Wartel, S., 1989. Palaeogeographical reconstruction of the offshore area off the Belgian coast - Acoustic investigations. In: Baeteman, C. (ed.): Quaternary sea-level investigations from Belgium, Ministerie van Economische Zaken. Geologische Dienst van België (Brussel): 92-104.

Whitehouse, R.J.S., Damgaard, J.S. \& Langhorne, D.N., 2000. Sandwaves and seabed engineering: the application to submarine cables. In: Trentesaux, A. \& Garlan, T. (eds): Marine Sandwave Dynamics, International Workshop (Lille): 227-234. 